\begin{tabular}{|l|l|l||}
\hline \multicolumn{2}{|c|}{ PublisherInfo } \\
\hline \hline PublisherName & $:$ & BioMed Central \\
\hline \hline PublisherLocation & $:$ & London \\
\hline \hline PublisherImprintName & $:$ & BioMed Central \\
\hline \hline
\end{tabular}

\title{
'Respiratory burst' enzyme found
}

\begin{tabular}{|l|l|l||}
\hline \multicolumn{2}{|c|}{ ArticleInfo } \\
\hline \hline ArticleID & $:$ & 5020 \\
\hline \hline ArticleDOI & $:$ & $10.1186 /$ gb-spotlight-20041210-02 \\
\hline \hline ArticleCitationID & $:$ & spotlight-20041210-02 \\
\hline \hline ArticleSequenceNumber & $:$ & 83 \\
\hline \hline ArticleCategory & $:$ & Research news \\
\hline \hline ArticleFirstPage & $:$ & 1 \\
\hline \hline ArticleLastPage & $:$ & 3 \\
\hline \hline & $:$ & RegistrationDate : 2004-12-10 \\
ArticleHistory & $:$ & OnlineDate \\
\hline \hline ArticleCopyright & $:$ & BioMed Central Ltd2004-12-10 \\
\hline \hline ArticleGrants & $:$ & \\
\hline \hline ArticleContext & $:$ & 130595511 \\
\hline \hline
\end{tabular}




\section{Clementine Wallace}

Email: wclementine@hotmail.com

Researchers have identified a key enzyme in the fertilization process of sea urchin eggs, which represent a common model for animal fertilization, according to a study (Dev Cell 2004, 7:801-814) published in the December 7 issue of Developmental Cell.

Working on two species of urchins, Strongylocentrotus purpuratus and Lytechinus variegatus, biologists at Brown University identified a dual oxidase, "Urchin Dual Oxidase" (Udx1), as the enzyme responsible for the typical "respiratory burst" observed at fertilization. During this burst, extracellular oxygen is turned into hydrogen peroxide, which is released into the perivitelline space around the egg.

"This respiratory burst has been a puzzle since the beginning of the century," Victor Vacquier from the Scripps Institution of Oceanography in La Jolla, Calif., who did not participate in the study, told us. "Then 20 years ago, we realized that the oxygen was actually being used to produce peroxide, but the mechanism still remained unclear."

During fertilization, the entry of the sperm into the egg immediately triggers a series of metabolic reactions to avoid polyspermy and protect the fragile embryo.

The major factor blocking other male gametes from entering the zygote is the depolarization of the membrane. That is followed by the transformation of the vitelline layer around the embryo into a hardened fertilization envelope, which insulates the egg in a more general manner from its environment. The polymerization of this matrix is catalyzed by the enzyme ovoperoxidase, whose indispensable substrate is peroxide.

"Disruption of any of these activities, which more or less happen in concert, results in compromised fertilization," said study co-author Gary Wessel.

To quantify when and how much peroxide is synthesized at fertilization, the researchers used an imaging photon detector. After discovering the oxidative burst activity is located at the cell surface, they set out to identify the enzymes involved.

While other cells known to produce peroxide - such as neutrophils, which release peroxide to kill invading organisms - usually do not survive this synthesis, the embryo remains immune to peroxidase. Until now, how this protection occurs remained unclear.

"The pharmacology of white blood cells is pretty well known, and there are many drug inhibitors of that oxidase," Wessel told us. "When using such inhibitors, our results showed that, indeed, an oxidase is in play, but not the type that blood cells use.

The team then identified the dual oxidase sequence in the sea urchin's genome, and polymerase chain reaction tests revealed the enzyme is expressed especially in developing oocytes. With the use of antiUdx 1 polyclonal antibodies, the team localized the specific enzyme in the cell membrane and verified it is, alone, responsible for peroxide synthesis. 
"Neutrophils are disposable cells. The egg isn't, and it has to be protected," said David Epel from Stanford University's Hopkins Marine Station, who did not participate in the study. "The enzyme they discovered in the egg has a dual role: At one end it's making peroxide, and at the other it's destroying it. So it pours the peroxide outside of the cell but also doesn't let it get inside the cell."

While evidence shows that $\mathrm{Udx} 1$ activation is calcium dependent, the team is now trying to understand how the enzyme shuts off after fertilization. "Clearly, if the embryo was producing peroxide for long periods of time, the embryo would be compromised," said Wessel, who suggested that Udx1 might also have a role in further development stages of the embryo.

A similar peroxidase activity can be found in a variety of animal eggs, such as those of mice, amphibians, and mosquitoes, according to the study. "This suggests this activity - making hydrogen peroxide a component of the block to polyspermy - could be evolutionarily very old and very widespread," said Vacquier.

\section{References}

1. Holding C: Sperm mRNA found in eggs The Scientist, May 13, 2004., [http://www.the-scientist.com/ news/20040513/01/]

2. Devevelpmental Cell, [http://www.developmentalcell.com]

3. Victor Vacquier, [http://vacquierlab.ucsd.edu/]

4. Gary Wessel, [http:/www.brown.edu/Departments/Molecular_Biology/facultypages/wesselg.html]

5. David Epel, [http://www.stanford.edu/ depel/] 